\title{
Urban Critical Infrastructure's Governance Framework for Climate Resilient Cities
}

\author{
By Cinta Lomba-Fernández ${ }^{1}$, Leire Labaka, Josune Hernantes
}

\begin{abstract}
Climate change affects cities worldwide conditioning their sustainable development. Cities will concentrate around $70 \%$ of the world population by 2050 accounting for $75 \%$ of the world's resources consumption. For that reason, cities must act against climate change adopting resilience strategies. Resilience strategies recognize the importance of the reliability and functioning of urban critical infrastructures as they provide essential services for the citizens and they are crucial for the resolution and recovery of the crises. However, the integration of critical infrastructures in the city climate resilience strategies is challenging because critical infrastructures are complex systems, strongly interconnected one to each other and generally, they belong or are operated by private companies. This research proposes a governance framework for better integration of the management of urban critical infrastructures into the city climate resilience strategy. The framework has been developed from academic literature and has been enriched with insights from workshops and interviews with experts and practitioners. As a result, the framework tackles four aspects of governance: (1) modes of governance; (2) stakeholders' roles; (3) processes and (4) instruments. These aspects will help to improve the vertical integration, cross-sectorial coordination, innovation and knowledge, and cooperation needed for improving city resilience.
\end{abstract}

Keywords: City Resilience; Urban Critical Infrastructures; Governance Framework; Climate Change Adaptation

\section{Introduction}

Climate change (CC) represents nowadays one of the most important challenges all over the world. CC impacts affect the natural ecosystems and the urban environment, affecting today peoples' lives and compromising their future (Füssel et al., 2017). Human activities contribute to $\mathrm{CC}$ to a large degree, the main causes are greenhouse gas emissions and the modification of natural ecosystems due to the use of natural resources. Moreover, cities today concentrate most of the world's population accounting for $75 \%$ of the world's resources consumption (Ribeiro \& Pena Jardim Gonçalves, 2019) and are situated mostly on coastlines. These facts make cities especially vulnerable to the impacts of CC such as sea-level rise, the increase in the frequency and intensity of the extreme weather events like hurricanes, or the long-term stressors like droughts. It could be said that cities play a double role regarding CC becoming part of the problem but also being an essential part of the solution through the adoption of measures to deal with CC.

Cities constitute socio-ecological systems of people, infrastructures and services. In particular, daily life in cities is highly dependent on critical services, such as water, energy, food or health, which are provided by Critical Infrastructures (CIs). CIs form extensive and complex networks, strongly interconnected to each other (Ouyang \& Wang, 2015). 
These networks are affected by CC impacts. Cities' action in the field of CC adopts the form of mitigation and adaptation measures. The standard approach to planning for climate adaptation relies on predictions based on CC scenarios. However, recent studies demonstrate there is uncertainty associated with those scenarios, as climate conditions are becoming increasingly variable and dynamic. This high degree of uncertainty requires resilience strategies that consider the dynamics of the threats.

City resilience can be defined as "the capacity to resist, absorb, adapt to and recover from shocks and stresses, to keep critical services functioning, to monitor and learn from on-going processes through city and cross-regional collaboration, and to increase adaptive abilities and strengthen preparedness by anticipating and appropriately responding to future challenges" (Hernantes et al., 2019). Resilient cities must reach a good combination of effective governance and leadership, adequate and reliable infrastructures and collective capacity and preparedness to afford challenges. Most of the city resilience frameworks recognize the importance of CIs in the resilience strategy, not only due to their role on the proper functioning of the city but also due to their importance in crisis response and recovery (ARUP, 2015). Some of these frameworks introduce methods to carry out an interdependencies analysis as part of the city resilience framework, analysing the cascading effects to avoid major disruptions (LombaFernández et al., 2019). However, many authors agree on the fact that the governance of urban CIs, and in particular the governance of interdependencies, is one of the problems that still need to be solved when developing city resilience (Monstadt \& Schmidt, 2019; Romero-Lankao et al., 2018). CIs usually are operated by private companies, for that reason cities need an adequate governance framework and instruments to guarantee the integration of urban CIs networks within the city resilience strategy against CC.

In general, the term governance refers to the structures, actions, traditions and processes by which authority is exercised, about the way people in societies share power and collective decisions are taken and implemented (Florin, M. V., \& Bürkler, 2017; Folke et al., 2005). Governance in the field of CC has evolved from a resources management approach to a more dynamic approach driven by the phenomena associated with CC. In this context emerges the concept of adaptive governance, concerning the actions carried out for CC adaptation.

Governance provides the context needed to guarantee that the action against CC is managed adequately, following the principles of good governance defined by the UNDP (1997): transparency; accountability and responsiveness. Related to the institutional structure, CC requires multilevel governance systems. In this sense, vertical integration among all institutional levels (international, national, regional and local) of decision making and intervention is required (Bauer et al., 2014). Moreover, CC needs of horizontal coordination across sectors as CC strategy and action requires an integral approach (Bauer et al., 2014). The institutional structure must guarantee the participation of all levels and sectors of society leaving no one behind. Especially at the local level, action against CC requires the involvement of many stakeholders. The governance system must provide the context and the means to ensure the cooperation and collaboration of all the Stakeholders (public, private and people networks and individuals), developing commitment, trust and awareness to guarantee the adoption and implementation of CC policies (Gimenez et al., 2017; Klein et al., 2018; Marana et al., 2018; Mees et al., 2019; Wamsler, 2017). Due to 
the dynamic and uncertain nature of CC, the governance system needs the capacity to cope with changes and uncertainty. The governance system must be able to identify, generate and integrate new knowledge and innovations. This knowledge comes from different sources, formal or informal, expert or non-expert, local or traditional knowledge, including processes of knowledge co-creation with the end-users. In this sense, urban labs and experiments are ultimately being considered as governance instruments at the local level. Moreover, flexibility is required, institutional flexibility to respond to future uncertainties but also flexibility among stakeholders to reach agreements, consensus and collaboration. Figure 1 shows these characteristics of governance identified in the literature.

\section{VERTICAL INTEGRATION

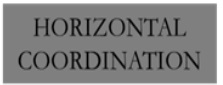 \\ PARTICIPATION

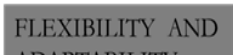 \\ INNOVATION AND KNOWLEDGE \\ COOPERATION AND}

Figure 1: Characteristics of governance

This research focuses on the governance dimension of city resilience and proposes a governance framework for better integration of the management of the urban CIs into the city climate resilient strategy. The framework aims to help cities in the selection of the most suitable governance model for the development and implementation of the CIs related city resilience strategy.

\section{Methods}

The framework proposed in this research seeks to define how the governance dimension of resilience can be developed to better integrate the urban CIs in the city climate resilience strategy. The results presented in this paper were obtained from a systematic literature review carried out in the Scopus and Google Scholar databases and complemented with other relevant publications such as reports or city resilience and climate change strategies. The systematic literature review was limited to journal articles in English published between 2011-2019. The initial search was conducted by looking up publications containing the words governance, climate change, resilience and adaptation, in the title, abstract or keywords. To refine the number of publications, the search was limited to European countries and specific areas of study: environmental, engineering and urban studies. Finally, manual filtering was done reading the abstracts. Moreover, articles that focus on urban critical infrastructures' resilience were identified. Figure 2 summarizes the process followed. 
Initial Search Query: ("climat* change" AND “governance" AND ("Adaptation” OR "Resilienc*”)) in the title, abstract or keywords

\begin{tabular}{|l|l|c|c|c|c|c|}
\hline SCOPUS & Total & INITIAL & \multicolumn{2}{|c|}{$\begin{array}{c}\text { Refining by European } \\
\text { countries and areas of study }\end{array}$} & $\begin{array}{c}\text { After reading } \\
\text { the abstracts }\end{array}$ \\
\cline { 2 - 6 } & $\begin{array}{l}\text { Adaptation } \\
\text { Resilience }\end{array}$ & 1247 & 497 & 184 & 100 \\
\hline
\end{tabular}

\begin{tabular}{|l|l|c|c|c|c|c|}
\hline GOOGLE & Total & INITIAL & \multicolumn{2}{c}{$\begin{array}{c}\text { Refining by European } \\
\text { countries and areas of study }\end{array}$} & $\begin{array}{c}\text { After reading } \\
\text { the abstract }\end{array}$ \\
\hline SCHOLAR & $\begin{array}{l}\text { Adaptation } \\
\text { Resilience }\end{array}$ & 1590 & 627 & 163 & 118 \\
\hline
\end{tabular}

Focused on urban critical infrastructures' resilience

Figure 2: Summary of the literature review process.

The resulting publications provided a theoretical basis to develop the framework. Once the main aspects of the framework were defined, they were contrasted with information obtained from two workshops with experts carried out in two cities in Spain. These workshops were organised in the context of a project for improving city climate resilience, and experts and practitioners in the field of CIs and local authorities took part in them. Table 1 shows the affiliation and the area of knowledge of the participants in the workshops.

Table 1. Affiliation and area of knowledge of the experts.

\begin{tabular}{|l|l|}
\hline AFFILIATION & AREA OF KNOWLEDGE (Number of Experts) \\
\hline City Council (Cities 1 and 2) & Environment and climate change adaptation (4) \\
\hline City Council (Cities 1 and 2) & Urban infrastructure maintenance (3) \\
\hline $\begin{array}{l}\text { City Council (City 1) } \\
\text { City Council (City 2) }\end{array}$ & Strategy development (2) \\
\hline $\begin{array}{l}\text { Osakidetza (Basque Country's public } \\
\text { health service) }\end{array}$ & Health (4) \\
\hline $\begin{array}{l}\text { Basque water agency. } \\
\text { Provincial water agency. } \\
\text { Aguas del Añarbe. }\end{array}$ & Water (3) \\
\hline $\begin{array}{l}\text { REE. } \\
\text { Iberdrola }\end{array}$ & Energy (electricity) (3) \\
\hline $\begin{array}{l}\text { DonostiTIK } \\
\text { Municipal police (City 2). } \\
\text { Ertzaintza (Basque Country's police force) }\end{array}$ & Safety and order (3) \\
\hline $\begin{array}{l}\text { Provincial council's firefighters } \\
\text { DYA. } \\
\text { Red Cross. } \\
\text { Civil Protection. }\end{array}$ & First responders (1) \\
\hline
\end{tabular}




\section{Results}

The resulting framework is composed of four components derived from the analysis of the literature, namely: modes of governance, actors and stakeholders, processes and instruments. These components are essential to reach the six characteristics of governance defined in the introduction section, needed for the success of the city climate resilience strategies. The framework aims to help in the development of the strategies by identifying how the components must be developed to guarantee the characteristics. Figure 3 summarizes the components of the proposed governance framework.

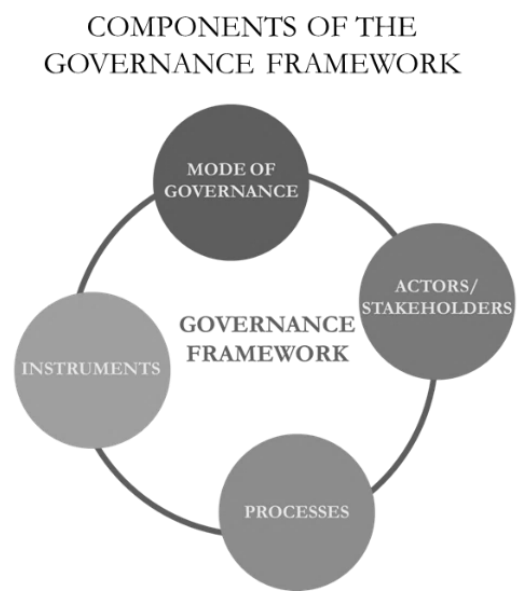

Figure 3: Governance framework

The four components of the governance framework, are explained below.

\subsection{Modes of Governance}

The mode of governance refers to how collective actions are coordinated to reach collective goals (Lange et al., 2013). In this sense, the modes of governance in the field of CC action sets out how the authority is exercised and influences the definition and implementation of the adaptation and mitigation policies, and therefore their impacts. Both resilience and adaptation to CC are cross-cutting strategies that apply to many areas. There are three main modes of governance, also known as classical or ideal types (Bauer et al., 2014; Bednar \& Henstra, 2018; Pahl-Wostl, 2019):

- $\quad$ Hierarchical: This mode involves different levels of authority. The authority is exercised by the state actors in a top-down direction, by command and control via instruments like regulation and legislation. Other stakeholders participate by being information providers or "passive rules adopters". This mode reports some weaknesses such as lack of flexibility and lack of consensus as it does not take into account societal inputs.

- $\quad$ Market: The market mode of governance adopts offer and demand rules thus, the direction of authority is circular as a result of a competition and negotiation among 
market actors. Main stakeholders are market participants, state and non-state, and seek mainly material profit.

- $\quad$ Network: The main characteristic of this mode of governance is the existence of a plurality of inputs, being a mode of governance more participatory and flexible than the previous ones. The bases of this mode are cooperation, trust and reciprocity among participants. The authority is shared and exercised in a horizontal direction looking for the benefit of all the participants. This fact facilitates to promote the innovation needed to address difficult policy problems. Government is a partner that interacts with others like the private sector or the citizens. On the opposite side, some weaknesses of this mode rely, such as the difficulty for reaching consensus or the voluntary character of the participation that can drive to a low commitment level. In this sense, the workshops revealed different opinions, while from the public sector they highlighted the need for the co-responsibility of all society against CC, from the private sector the claimed for political will for reaching common goals.

- Community: Bednar \& Henstra (2018) also distinguishes the fourth mode of governance, "community governance", which is characterized by a bottom-up approach and usually appears at the local level. It shares features with the network mode of governance but emphasizes the leverage role of communities.

Most authors agree on the fact that in CC a mixed of modes of governance is required to address mitigation, adaptation and resilience goals. The participants in the workshops agreed about the fact that for urban climate resilience, the network mode of governance seems to be the most appropriate due to its flexible and participative character. Moreover, they pointed out the challenge of involving all the stakeholders, required to address the dynamism and uncertainty associated with CC.

\subsection{Actors/Stakeholders}

As said before, urban climate resilience strategies need the involvement and commitment of a wide variety of actors. In recent years cities are adopting more collaborative modes of governance, such as network or community governance, due to their benefits in complex contexts. The application of those modes of governance requires a clear identification of the main actors and a definition of their roles in the governance process.

Gimenez et al., (2017) define city Stakeholders for city resilience as: "the individuals, groups or organizations within a city who can affect or are affected by the resilience building process such as the entities and departments from the local government".

Concerning to their classification, in the field of CC adaptation, Birkmann et al., (2010) distinguish among formal agencies (e.g., public administrations) and informal organizations (e.g., individual households, non-formalized social networks). Castán Broto, (2017) distinguish between State and Non-State actors, emphasizing the role of the individuals as active actors in climate action. At the local level, Wamsler, (2017) distinguishes among internal and external stakeholders. Internal stakeholders are the authorities' administration staff. While the parties or groups that are not a part of the municipality, but that are affected by its activities are called external stakeholders (for example citizens, municipalities and academia). 
Table 2 defines the main stakeholders' profiles and their roles in the governance of critical infrastructures for urban climate resilience. Based on the classification of stakeholders done by Gimenez et al 2017, this paper adapts and completes the list emphasizing the role of each stakeholder in the field of CC (Bauer et al., 2014; Castán Broto, 2017; Lee \& Painter, 2015; Wamsler, 2017). This table is a general proposal that may be adapted to the specific characteristics and needs of each city, including or excluding stakeholders if needed.

Table 2: Stakeholders participating in climate city resilience.

\begin{tabular}{|c|c|}
\hline STAKEHOLDER & ROLE (Urban CIs Climate Resilience) \\
\hline $\begin{array}{l}\text { SUPRANATIONAL } \\
\text { LEVELS OF } \\
\text { GOVERNMENT }\end{array}$ & $\begin{array}{l}\text { The State sets the national goals to be met by the counties' council } \\
\text { legislation and regulation, and by local activities. } \\
\text { Play a crucial role in informing regulation and enabling innovation. }\end{array}$ \\
\hline $\begin{array}{l}\text { REGIONAL } \\
\text { /COUNTY } \\
\text { GOVERNMENT }\end{array}$ & $\begin{array}{l}\text { Development and implementation of regional plans, for ensuring the } \\
\text { resilience of the territory, in coordination with national and } \\
\text { international institutions. For example, sectorial plans for energy or } \\
\text { water. } \\
\text { Responsible for implementing national decisions at the regional level. } \\
\text { Coordination of efforts and resources to reinforce the existing ones or } \\
\text { replace them when they do not exist at the local level. }\end{array}$ \\
\hline $\begin{array}{l}\text { CITY COUNCIL } \\
\text { POLITICIANS }\end{array}$ & $\begin{array}{l}\text { Critical in the city resilience-building process as they are close to the } \\
\text { citizens. Provide strategic planning vision to better respond to disaster } \\
\text { risks and for ensuring the continuity of the service of the city. Provide } \\
\text { funding. Interact with other stakeholders. } \\
\text { Lead the CC action at the local level: developing climate change } \\
\text { policies, allocating financial and human resources, coordinating } \\
\text { municipal departments. } \\
\text { Responsible for spatial planning and emergency preparedness, health } \\
\text { and social protection. }\end{array}$ \\
\hline $\begin{array}{l}\text { LOCAL } \\
\text { GOVERNMENT } \\
\text { MUNICIPAL STAFF } \\
\text { (Civil servants and } \\
\text { others) }\end{array}$ & $\begin{array}{l}\text { Provide technical expertise for urban CIs planning with a holistic view. } \\
\text { Planning and implementing policies. } \\
\text { Act as drivers for CC action. }\end{array}$ \\
\hline $\begin{array}{l}\text { EMERGENCY } \\
\text { SERVICES }\end{array}$ & $\begin{array}{l}\text { Provide security and safety to citizens by reducing, preparing and } \\
\text { responding to disasters risks. Provide public education, alert and } \\
\text { warning systems and disaster plans. They must coordinate efforts, } \\
\text { plans, training and resources with CI providers. }\end{array}$ \\
\hline $\begin{array}{l}\text { CRITICAL } \\
\text { INFRASTRUCTURES }\end{array}$ & $\begin{array}{l}\text { Provide essential needs to the citizens. Their adequate functioning in } \\
\text { case of emergencies is crucial. Provide expert knowledge about } \\
\text { technical aspects, interdependencies and emergency planning. } \\
\text { Coordinate their actions with other CIs and the government at the } \\
\text { local, regional and national level. } \\
\text { Responsible for adopting and propose mitigation and adaptation } \\
\text { measures to reach CC and resilience goals. }\end{array}$ \\
\hline
\end{tabular}




\begin{tabular}{|c|c|}
\hline $\begin{array}{l}\text { CTORIAL } \\
\text { PERTS (State and } \\
\text { l-state) }\end{array}$ & Knowledge providers. \\
\hline $\begin{array}{l}\text { ACADEMIC, } \\
\text { EDUCATIONAL and } \\
\text { SCIENTIFIC } \\
\text { ENTITIES }\end{array}$ & $\begin{array}{l}\text { Increase the knowledge and develop methodologies to build city } \\
\text { resilience. } \\
\text { Contribute to promote resilience and raise awareness of disaster } \\
\text { management among children and communities. } \\
\text { Provider of scientist expertise and knowledge on climate change } \\
\text { mitigation and adaptation, analysis of the CIs and their } \\
\text { interdependencies. } \\
\text { Consulting governance members for decision making. }\end{array}$ \\
\hline CITIZENS & $\begin{array}{l}\text { Initiate action by advocating for change and influencing decisions from } \\
\text { the government. } \\
\text { Successful actions in cities will also have to come from the leadership } \\
\text { shown by citizens groups, community organizations, technical } \\
\text { institutions and the private sector. Knowledge providers. } \\
\text { Responsible for protecting own property. }\end{array}$ \\
\hline MEDIA & $\begin{array}{l}\text { Companies are in charge of disseminating hazard information and early } \\
\text { warning measures. Social media and ICTs contribute to the } \\
\text { dissemination of information on disasters, plans in place and protection } \\
\text { measures to city stakeholders. }\end{array}$ \\
\hline $\begin{array}{l}\text { PUBLIC AND } \\
\text { PRIVATE } \\
\text { COMPANIES }\end{array}$ & $\begin{array}{l}\text { Provide resources, sponsorship, guidance and workforce to prepare, } \\
\text { respond and recover from disasters. Need to be engaged in awareness- } \\
\text { raising and training programs to be prepared. }\end{array}$ \\
\hline $\begin{array}{ll}\text { NON-STATE } & \\
\text { ACTORS } & \text { like } \\
\text { BUSINESSES; } & \\
\text { NETWORKS } & \text { or } \\
\text { COMMUNITIES } & \end{array}$ & $\begin{array}{l}\text { Open up new areas of intervention and supporting action where there } \\
\text { is not enough capacity. }\end{array}$ \\
\hline $\begin{array}{l}\text { OTHER } \\
\text { MUNICIPALITIES } \\
\text { and CITY } \\
\text { NETWORKS }\end{array}$ & $\begin{array}{l}\text { Provide or reinforce local resources for responding to CC crises. } \\
\text { Increase preparation by sharing knowledge, best practices and lessons } \\
\text { learned. } \\
\text { Support networks that provide knowledge, tools and support for } \\
\text { developing and implementing CC strategies. } \\
\text { They have a bridging function facilitating the communication and } \\
\text { integration of both scientific and local knowledge, and also serve to } \\
\text { encourage diversity and mobilize social capital. }\end{array}$ \\
\hline $\begin{array}{l}\text { ENVIRONMENTAL } \\
\text { AGENCIES }\end{array}$ & $\begin{array}{l}\text { Innovation enablers. Facilitators for the city council and CIs. } \\
\text { Acts as drivers and expert knowledge for the development and } \\
\text { implementation processes. }\end{array}$ \\
\hline
\end{tabular}

\subsection{Processes}

To fulfil the role of governance some essential processes must be carried out. These processes are called functions by (Pahl-Wostl, 2019) or governance choices by (Huitema et al., 2016). The most representative are described below:

- Knowledge generation and integration. Cities must develop adaptation and resilient capacities to deal with CC considering the uncertainty associated with it. Thus, the governance model needs processes to identify, generate and include knowledge. 
Knowledge can come from different sources, formal or informal. Also different types of knowledge: expert, local, traditional. The modes of governance differ in how these processes are developed. In hierarchical modes of governance, they prioritize the expert knowledge. While in modes of governance such as network or community, processes that let the knowledge co-creation, including end-users, are required. In this sense, processes to facilitate the adoption of innovative bottom-up initiatives, and their institutionalization are needed.

- Conflict resolution. Due to its cross-cutting approach, climate resilience strategies coexist with other strategies, not being always well-integrated. Conflicts of competences or interests, about how the resources and instruments should be allocated and how to prioritize the different fields are frequent. Governance modes define how conflicts are solved. In the case of CIs, for example, conflicts can come due to the variety of interests of the private companies or related to the regulation or the technical requirements of the infrastructures. In this sense, CIs providers complain that they are not taken into account when developing these policies.

- Monitoring and evaluating. The governance model must provide processes to monitor the implementation process, the evolution of the main indicators and the impact of the policies and measures. Monitoring processes must include CIs. These processes are aligned with the principles of accountability and transparency of good governance.

\subsection{Instruments}

Cities develop their climate resilience strategies in a specific temporal, cultural, economical and legal context. In this sense, mitigation and adaptation to CC emerge initially in the field of environmental regulation (Keskitalo et al., 2016). However, CC projections for the coming years pointed out the need for a cross-cutting approach, involving other areas and interacting with other fields' regulations, i.e. sectorial regulations like energy or water. Moreover, the trend is to move towards more participative modes of governance like networks or community, which involves a wide variety of stakeholders. All these facts make necessary the use of different instruments to facilitate the governance processes and to overcome the barriers that appear in the development and implementation of the climate resilience policies. We understand instruments as the tools used in the exercise of governance to implement the policies. Table 3 identifies the most common instruments associated with the modes of governance explained before.

Table 3: Instruments associated with each mode of governance. Own elaboration extracted mainly from (Klein et al., 2018; Pahl-Wostl, 2019; Wamsler, 2017).

\begin{tabular}{|l|l|l|}
\hline Mode of Governance & Instrument & Examples \\
\hline Hierarchical & $\begin{array}{l}\text { Regulation and laws. } \\
\text { Incentives. }\end{array}$ & $\begin{array}{l}\text { Bonuses for the reduction of greenhouse } \\
\text { gas emissions: reduction of municipal } \\
\text { taxes for low-emission vehicles in San } \\
\text { Sebastian (Spain) }\end{array}$ \\
\hline Market & $\begin{array}{l}\text { Supply and demand. } \\
\text { Advisory boards. } \\
\text { Coordination bodies. }\end{array}$ & $\begin{array}{l}\text { At the city level, the implementation of } \\
\text { measures such as green purchasing } \\
\text { criteria. }\end{array}$ \\
\hline
\end{tabular}




\begin{tabular}{|l|l|l|}
\hline \multirow{5}{*}{ Network } & $\begin{array}{l}\text { Self-Regulation. } \\
\text { Negotiated agreements. } \\
\text { Codes of practice. } \\
\text { Consultation processes. } \\
\text { Voluntary programs. }\end{array}$ & $\begin{array}{l}\text { San Sebastian (Spain) CC Strategy } \\
\text { includes the analysis of the CIs } \\
\text { interdependencies. The strategy has } \\
\text { involved different agents in the } \\
\text { development process. }\end{array}$ \\
\hline Open public deliberation. \\
Educational campaigns to to \\
inform local participants. \\
Direct democracy and \\
voluntary uptake via civic \\
commitment. \\
Experiments. \\
Urban labs.
\end{tabular}

\section{Discussion}

This paper aimed to present a framework developed through a literature review and the insights from two workshops carried out in Spain. The framework establishes four components of governance for ensuring a good development of the characteristics of governance. Once these components have been identified, it is necessary to understand how they influence the characteristics. Some initial findings are, for example, that to reach the vertical integration among institutional levels hierarchical modes of governance could be appropriate to guarantee the alignment of the policies. Moreover, elements of the market mode of governance would be needed for the alignment of the sectorial strategies including the private sector. The identification of the processes that should be developed, the key stakeholders that should participate in and their roles, and the selection of the adequate instruments such as regulation or incentives will help in the proper vertical integration. However, in the case of horizontal coordination, the adoption of network or community modes of governance seems to be more appropriate, and the stakeholders and their roles would be not the same, neither the instruments. In this case, for example, instruments such as advisory boards, consultation processes or experiments would be more convenient since they facilitate the generation of knowledge, as well as the engagement and commitment of the stakeholders. Further research needs to be conducted about all these aspects.

\section{Conclusion}

This paper focuses on the development of the governance dimension of city resilience. A governance framework for urban CIs to improve city climate resilience is proposed. We have identified the general characteristics of effective and good governance systems, and then we have defined which aspects must be considered to reach those characteristics and we have called them components. Moreover, we suggest that the four components of the governance framework have a direct impact on the desired characteristics of the governance system.

However, further research must be conducted to better establish the relationship between the components and the characteristics in the governance framework, to 
identify the components' drivers. Moreover, this relationship must be specified in the case of urban critical infrastructures for city resilience.

\section{Acknowledgements}

This research is funded by the Fundación AON.

\section{References}

ARUP. (2015). City Resilience Framework. ARUP Group Ltd, November, http://www.rockefellerfoundation.org/

Bauer, A., Feichtinger, J., \& Steurer, R. (2014). The Governance of Climate Change Adaptation in 10 OECD Countries: Challenges and Approaches Countries: Challenges and Approaches. October 2014, 37-41. https://doi.org/10.1080/1523908X.2012.707406

Bednar, D., \& Henstra, D. (2018). Applying a Typology of Governance Modes to Climate Change Adaptation. Politics and Governance, 6(3), 147. https://doi.org/10.17645/pag.v6i3.1432

Birkmann, J., Garschagen, M., Kraas, F., \& Quang, N. (2010). Adaptive urban governance: New challenges for the second generation of urban adaptation strategies to climate change. Sustainability Science, 5(2), 185-206. https://doi.org/10.1007/s11625-010-0111-3

Castán Broto, V. (2017). Urban Governance and the Politics of Climate change. World Development, 93, 1-15. https://doi.org/10.1016/j.worlddev.2016.12.031

Florin, M. V., \& Bürkler, M. T. (2017). I. to the I. R. G. F. (No. R. I. R. G. C. (IRGC). (2017). INTRODUCTION TO THE IRGC RISK GOVERNANCE.

Folke, C., Hahn, T., Olsson, P., \& Norberg, J. (2005). Adaptive Governance of Social-Ecological Systems. Annual Review of Environment and Resources, 30(1), 441-473. https://doi.org/10.1146/annurev.energy.30.050504.144511

Fröhlich, J., \& Knieling, J. (2013). Conceptualising climate change governance. Climate Change Management, 926. https://doi.org/10.1007/978-3-642-29831-8_2

Füssel, H.-M., Jol, A., Marx, A., Hildén, M., Aparicio, A., Bastrup-Birk, A., Bigano, A., Castellari, S., Erhard, M., Georgi, B., Isoard, S., Kendrovski, V., Kristensen, P., Kurnik, B., Leitner, M., Louwagie, G., Lung, T., Mysiak, J., Olesen, J., ... Gisle, L. (2017). Climate change, impacts and vulnerability in Europe 2016. In Research Policy (Vol. 46, Issue 1). https://doi.org/10.2800/534806

Gimenez, R., Labaka, L., \& Hernantes, J. (2017). Technological Forecasting \& Social Change A maturity model for the involvement of stakeholders in the city resilience building process. Technological Forecasting \& Social Change, 121, 7-16. https://doi.org/10.1016/j.techfore.2016.08.001

Hernantes, J., Maraña, P., Gimenez, R., Sarriegi, J. M., \& Labaka, L. (2019). Towards resilient cities: A maturity model for operationalizing resilience. Cities, 84, 96-103. https://doi.org/10.1016/J.CITIES.2018.07.010

Huitema, D., Adger, W. N., Berkhout, F., Massey, E., Mazmanian, D., Munaretto, S., Plummer, R., \& Termeer, C. C. J. A. M. (2016). The governance of adaptation: Choices, reasons, and effects. Introduction to the special feature. Ecology and Society, 21(3). https://doi.org/10.5751/ES-08797210337

Keskitalo, E. C. H., Juhola, S., Baron, N., Fyhn, H., \& Klein, J. (2016). Implementing local climate change adaptation and mitigation actions: The role of various policy instruments in a multi-level governance context. Climate, 4(1). https://doi.org/10.3390/cli4010007

Klein, J., Araos, M., Karimo, A., Heikkinen, M., Ylä-Anttila, T., \& Juhola, S. (2018). The role of the private sector and citizens in urban climate change adaptation: Evidence from a global assessment of large cities. Global Environmental Change, 53(October), 127-136. https://doi.org/10.1016/j.gloenvcha.2018.09.012

Lange, P., Driessen, P. P. J., Sauer, A., Bornemann, B., \& Burger, P. (2013). Governing Towards Sustainability-Conceptualizing Modes of Governance. Journal of Environmental Policy and Planning, 15(3), 403-425. https://doi.org/10.1080/1523908X.2013.769414

Lee, T., \& Painter, M. (2015). Comprehensive local climate policy: The role of urban governance. Urban 
Climate, 14, 566-577. https://doi.org/10.1016/j.uclim.2015.09.003

Lomba-Fernández, C., Hernantes, J., \& Labaka, L. (2019). Guide for climate-resilient cities: An urban critical infrastructures approach. Sustainability (Switzerland), 11(17). https://doi.org/10.3390/su11174727

Marana, P., Labaka, L., \& Sarriegi, J. M. (2018). A framework for public-private-people partnerships in the city resilience-building process. Safety Science, 110, 39-50. https://doi.org/10.1016/J.SSCI.2017.12.011

Mees, H. L. P., Uittenbroek, C. J., Hegger, D. L. T., \& Driessen, P. P. J. (2019). From citizen participation to government participation: An exploration of the roles of local governments in community initiatives for climate change adaptation in the Netherlands. Environmental Policy and Governance, 29(3), 198-208. https://doi.org/10.1002/eet.1847

Monstadt, J., \& Schmidt, M. (2019). Urban resilience in the making? The governance of critical infrastructures in German cities. Urban Studies, 56(11), 2353-2371. https://doi.org/10.1177/0042098018808483

Ouyang, M., \& Wang, Z. (2015). Resilience assessment of interdependent infrastructure systems: With a focus on joint restoration modelling and analysis. Reliability Engineering and System Safety, 141, 74-82. https://doi.org/10.1016/j.ress.2015.03.011

Pahl-Wostl, C. (2019). The role of governance modes and meta-governance in the transformation towards sustainable water governance. Environmental Science and Policy, 91(October 2018), 6-16. https://doi.org/10.1016/j.envsci.2018.10.008

Ribeiro, P. J. G., \& Pena Jardim Gonçalves, L. A. (2019). Urban resilience: A conceptual framework. In Sustainable Cities and Society. https://doi.org/10.1016/j.scs.2019.101625

Romero-Lankao, P., Bruns, A., \& Wiegleb, V. (2018). From Risk to WEF Security in the City: the Influence of Interdependent Infrastructural Systems. Environmental Science and Policy. https://doi.org/10.1016/j.envsci.2018.01.004

Wamsler, C. (2017). Stakeholder involvement in strategic adaptation planning: Transdisciplinarity and coproduction at stake? Environmental Science and Policy, 75(March), 148-157. https://doi.org/10.1016/j.envsci.2017.03.016 